\title{
THE TRAGIC CONSEQUENCES OF THE CAPITALIST IMAGERY
}

\section{Daria S. Litova}

Universidade NOVA Lisboa, Portugal

d178@st-andrews.ac.uk

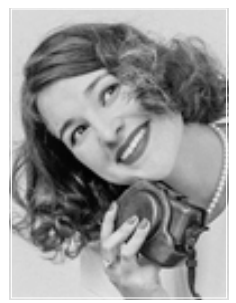

Abstract. Overproduction, consumerism and commodity fetishism - it seems like these tendencies are omnipotent and omnipresent in the modern world. The difference between the society criticized by Marx and the reality encompassing us is that in the postmodern societies, it is the information and images that serve as an object of consumption and consequently commodity fetishism. In other words, the service sector produces images that become the means of mediation. In the article, the author looks into the work of Stanislaw Lem Futurological Congress and contemporary French movie The Congress following the same plot. The analysis being founded on the theories of Guy Debord, Slavoj Žižek and Karl Marx, as well as the recent investigations of a journalist Naomi Klein, the author uncovers implicit consequences of the consumerist way of life, imposed on us by the capitalist system as well as media and transnational companies. Arguing, after Žižek, that the criticism of late-capitalism is directly linked to the understanding of the human psyche's recesses, the article attempts to explain the consumer turning into a marionette of large businesses. This position is further strengthened by the natural necessity for an individual to embrace the system's core impositions, in particular, to recognize the non-existing authenticity behind a brand. The tendency further leads to the alienation from real merit and overconfidence in the fairness inherent in the existing system. Overproduction and the ubiquitous loss of Walter Benjamin's Aura result in actual poverty behind the mask of abundance, nature of the art and authenticity becoming extinct. This leads to the natural drive to substitute the lost identity for the (re-) invented one and manifest individualities, sometimes aggressively and vigorously. As Lem's characters balance on the verge between reality and hallucinations, modern-day consumers lose the established coordinate system, distracted by the absolute and seemingly non-restricted liberty of choice, the virtual reality permitting to act out any repressed impulses and instincts fully and with impunity. Citing Debord, 'the poverty unites everyone involved in the spectacle and its controversies'. The author is of the opinion that Lem's Futurological Congress aims at forewarning the reader from the possibility of the imaginary system progressing irreversibly, the idea further reflected in the movie. There is no hope for a society abandoning the boundaries of reality and moral guidelines for good. The analysis could possibly describe the broadening sphere of influence of the multinational corporations and contribute to the lively discussions on the digital divide and the social networks' actual/ impact on society. 
Keywords: capitalism, postmodernism, Guy Debord, Slavoj Žižek, Marxism, futurism, French cinema, Stanislaw Lem, Society of the Spectacle, commodity fetishism, the social dilemma, digital divide

Acknowledgements: The author would like to thank Roman Ulanov for introducing her to the works of Stanislaw Lem and for the inspirational discussions on post-modern philosophy, contemporary culture, Neo-Marxism and the shifts in the world order

For citation: : Litova, D. S. (2021) 'The Tragic Consequence of the Capitalist Imagery', Concept: Philosophy, Religion, Culture, 5(1), pp. 169-177. https://doi.org/10.24833/2541-8831-2021-1-17-169-177

\title{
ТРАГИЧЕСКИЕ ПОСЛЕДСТВИЯ КАПИТАЛИСТИЧЕСКОЙ СИСТЕМЫ ОБРАЗОВ
}

\author{
Дарья Сергеевна Литова
}

Университет НОВА, Лиссабон, Португалия

dl78@st-andrews.ac.uk

\begin{abstract}
Аннотация. Перепроизводство, потребительская философия и товарный фетишизм - эти тенденции кажутся всемогущими и вездесущими. Возможно, разница между обществом, критикуемым Марксом, и окружающим нас современном миром заключается именно в том, что в постмодернистских обществах информация и образы служат наиболее желанным объектом потребления и, следовательно, «товарного фетишизма». Другими словами, сектор услуг производит образы, которые становятся «посредниками» в формировании социальных связей. В статье автор рассматривает работу Станислава Лема «Футурологический конгресс» и современный французский фильм «Конгресс», снятый по его мотивам. Основываясь на теориях Ги Дебора, Славоя Жижека и Карла Маркса, а также на недавних журналистских расследованиях Наоми Кляйн, автор раскрывает неявные последствия потребительского образа жизни, навязанного капиталистической системой, а также средствами массовой информации и транснациональными компаниями. Аргументируя, вслед за Жижеком, что критика позднего капитализма напрямую связана с пониманием глубин человеческой психики, автор статьи пытается объяснить, каким образом потребитель превращается в марионетку крупного бизнеса. Избыточное производство и повсеместная утрата беньяминовской ауры ведут к фактической бедности за маской изобилия. Это приводит к естественному стремлению заменить утраченную идентичность на придуманную. Подобно тому, как персонажи Лема балансируют на грани между реальностью и галлюцинациями, современные потребители теряют установленную систему координат, отвлекаясь на абсолютную и, казалось бы, неограниченную свободу выбора, виртуальную реальность, позволяющую в полной мере и безнаказанно реагировать на любые подавленные импульсы и инстинкты. Ссылаясь на Дебора, «бедность объединяет всех, кто участвует в спектакле и его противоречиях». Автор считает, что «Футурологический Конгресс» Лема нацелен на то, чтобы предостеречь читателя от возможности необратимого развития воображаемой системы, идея которой нашла дальнейшее отражение в фильме. Нет никакой надежды для общества, отказывающегося от границ реальности и моральных ориентиров. Данный анализ, возможно, позволит описать расширяющуюся сферу влияния транснациональных корпораций и внести свой вклад в оживленную дискуссию о цифровом разрыве и фактическом воздействии социальных сетей на общество.
\end{abstract}

Ключевые слова: капитализм, постмодернизм, Ги Дебор, Славой Жижек, марксизм, футуризм, французский кинематограф, Станислав Лем, общество спектакля, товарный фетишизм. 
Благодарности: Автор выражает признательность Роману Уланову за вдохновляющие дискуссии о философии, современных культуре, миропорядке и капитализме и за открытие мира работ Станислава Лема.

Для цитирования: Литова Д.С. Трагические последствия капиталистической системы образов // Концепт: философия, религия, культура. - 2021. - Т. 5, № 1. - С. 169-177. https://doi. org/10.24833/2541-8831-2021-1-17-169-177

G uy Debord, French left-wing revolutionary, philosopher and avant-garde director, in his work, promoted the idea of the Society of the Spectacle. By this term, he summarized the unwritten rules of the capitalist society, that in late-capitalist times, have more ramifications than ever.

He defines that the spectacle, 'social relations of people mediated by images' [Debord, 1995 , p. 4], accepted as a central characteristic of the modern-day society is the project and the consequence of consumerist behaviour. Artificial values constructed for profit, predominant producers' influence on minds, immersion in the world of desires and wishful thinking it is not a mere decoration added to the real world. They took hold in this real society's unreality [Debord, 1995, p. 6]. The existing mode of production imposes these features on our lives, be it social or personal.

In the article, I will apply two cultural theories to the analysis of capitalist society's escape to the virtual dimension. I will address Guy Debord's idea from the Marxist point of view, recalling Marx, Debord and Benjamin. As I understand it, the criticism of late-capitalism is directly linked to the understanding of the human psyche's recesses. For this reason, I incorporate in my analysis the ideas of Slavoj Žižek, Slovene philosopher and cultural theorist whose works comprise psychoanalysis, Marxism alongside with the critique of capitalism, and the popular culture studies.

In my opinion, the sphere of entertainment produces the major part of the cultural artefacts, contributing to 'the unrealism of the real society' [Debord, 1995, p. 6]. I will focus on the postmodern phenomena of images, virtual reality and mind games and their influence on how people lose the dwindling ground of reality, preferring not to notice the problems to solve.

The overabundance of mostly useless information could make us willing to disrupt this flow and delve into one's thoughts, isolating oneself from the blatant omnipresent voice of 'society' (solution, more natural of an introvert psychotype ${ }^{1}$ [Zizek, 1997, p. 195]). Alternatively, entirely on the contrary - raise the wish to relax and enjoy what is served for us. In this way, the individual renounces his or her symbolic order connected to the personal experience. Consuming external entertainment or products, one substitutes his impulses for the 'fantasies', deliberately and carefully generated by capitalist corporations. Moreover, according to Žižek, it is precisely the fantasy that teaches us what we desire and how to desire it [Zizek, 1997, p. 7]. Thoughtless consumption of commercial, 'fast-food' culture turns a person into a marionette of large businesses. 'Desire's raison d'être is not to realize its goal, to find full satisfaction, but to reproduce itself as desire' [2, p. 39] — and an individual becomes trapped in the vicious circle of consumerism, be it the one of goods or images of the show-business and the popular culture.

The Marxist theory opens the eyes to the commodity fetishism, which casually becomes a trap to any customer. The mechanism of this phenomenon has its roots in the symbolic perception of the world, intrinsic to human nature. To impose dependency on the goods, the

Žižek calls it 'informational anorexia - the desperate refusal to accept information, in so far as it occludes the presence of the Real' 
manufacturers undertake many steps, consequently determining the value of the product completely different from the real one. Commodities are endowed with the 'externally imposed fetishist aura', particular spiritual dimension [Zizek, 1997, p. 97].

Broadly, this situation results in corporate greed, environmental ruin, sweatshops and human misery. These consequences of our current mode of production are scrupulously depicted in the work of Canadian antiglobalist writer Naomi Klein, published in 1999 [3]. Sweatshops in the Third World whose conditions are close to slavery (in particular, special economic zones), harmful McDonaldization of society, impossibility to fight legally against large corporations - the arbitrariness of the capital.

What allows the large corporations to exploit the collective imagination at their will is the reduced importance of the aura in the object of the culture. This change in the perception of artistic works was first analyzed in the work of the German philosopher and cultural critic Walter Benjamin in 1936 [4]. Working in the paradigms of German Idealism and Western Marxism, the left-wing thinker explained the way the context, the aura, 'the here and now of the work of art' [Benjamin, Underwood, 2008 , p. 5] fall victims to the mechanical reproducibility on a large scale. Before this feature carried considerable clout. The most contextual, valuable and unique objects were the sacral ones - to the extent that they could be unveiled only several times a decade [Benjamin, Underwood, 2008, p. 10]. Revelation and reproduction frequently hamper creativity, the nature of the art, leading to its death. The remaining shell remains open for manipulations. Pristine turns futile. To a certain extent, that is the nature of postmodernism in the common perception.

The transformation applies to any sphere of the (post)modern life. Nowadays, behind the mask of abundance, there is actual poverty: there are many goods, but they are one- time items, and they are all the same (the interconnected features). It is the postmodern product - image, slogan, advertising - that becomes valuable.

Brands mastered the manipulations with this 'detached aura'. As such, they are entirely disconnected from the production of goods. On the contrary, they are based on the construction of a certain ethereal 'the only right' way of life. Through marketing and promotion, artificial principles are consistently embedded in the fabric of everyday life, symbolizing association with a specific social group and mediating human interactions, pushing people to the spending spree.

It is particularly important to note that a brand has a built-in semantics of authenticity, which is often difficult to challenge even a critically minded person. Consciousness and imagination captured by the brand perceive the consumer's actions as a result of his or her choice, but in reality, it was not a free one.

Žižek points out at the fact that in the fetishist system, consumers, 'victims of fetishist illusion', confuse the natural qualities of the product with the value connected to its place within the structure [Zizek, 1997, p. 105]. This constitutes the attitude of external distance, alienation from real merit. Though suspecting 'the dark side' of the existing order, a consumer entangles him- or herself in chains of false images. Thuswise I find it particularly important to focus on the phenomenon of the fetishism of images, implying that in postmodern society the illusion Žižek writes about correlates mainly to the exploitation of brands, be it corporative or personal ones ${ }^{2}$. It is indubitable that the sphere of entertainment possesses a massive percentage of the GDP of developed countries and often creates a specific sphere of influence - not for the governments, as in the Cold War era, but for the multinational corporations.

As an illustration let me introduce a fiction novel by the Polish philosopher, futurologist and writer Stanislaw Lem Futurological Con-

\footnotetext{
2 Wide-spread phenomenon of a personal brand nowadays exceeds the frame of the show business or a larger entertainment field. Due to the development of the social networks appearance makes money, and appearance is what matters. The number of imaginary Instagram- and YouTube- personas and their paid promoters and consultants grows, comprising a huge financial net. Is it not a true spectacle?
} 
gress [5] and its film adaptation ${ }^{3}$, which represent a particular interest. I will refer to both the book and the film, as they complement and divulge each other, to a certain extent creating intellectual duet.

The 1971 Lem's novel is a disappointing forecast for the development of human society in the context of increasing social confrontation and the rapid depletion of natural resources. In the book which could be recognized as a black humour science fiction, the ruling circles plunge all of humanity into a kind of virtual reality, an illusory world of almost complete abundance and prosperity, with the use of chemicals.

The Congress, French-Israeli science fiction film of 2013, is comprised of realistic and animation parts. The director recognizes the film as an adaptation of Stanislaw Lem's book. Reflecting the way, the consumerist society of today functions, this version focuses on the sphere of entertainment and its spreading influence on the minds and lives. The 1971 novel is the source of the idea of the extensive use of hallucinogens, supplemented by the director's inventions about digital scanning of actors.

The film develops the main points of the novel. The viewer can see at once: the fears of the future intrinsic to the mind of the Cold War era, provoked by the technical revolution, advertisement coven and limitless capitalist influence, are as urgent as ever.

The film consists of two parts.

In the first part, The Miramount film studio proposes to actress Robin Wright to sign a contract for them to use her image unconditionally, enjoying total impunity. Her son suffering from a rare illness consuming all her money and attention, she allows them save her digital copy, the company stripping her of the right to decide the terms of its use.

The second part takes place in the future twenty years later. The aged actress drives through the desert, the world slowly turning into its animation version. Robyn ('a cartoon' already) arrives at a huge hotel where an un- specified global congress opens. The spectator sees a variety of characters gropping in the dark, balancing on the verge between reality and hallucinations and trying to manifest their individualities - or to conceal them, assuming the appearances of famous people and fictional personas. Robyn Wright is preoccupied with finding her son suffering from vision and hearing impairment. In search of him and the truth, she wanders between the animated and the real worlds, at last plunging back in the fictional having perceived the scale of the global catastrophe.

The representation of the real and imaginary world both in the movie and the book is especially inquieting.

The writer and the director make us realise that the virtual reality on the screen is a direct citation of a capitalist society. Let us take as an example of the film episode with the lottery. The behaviour of the crowd derives from either complete madness or the daily life of America's stock market ${ }^{4}$. There we can see the cartoon characters whose appearance resembled skewed caricatures. Those engaged in a lottery, are evidently inspired by the antibourgeois cartoons from the Soviet imagination. The managers look like exemplary executives from American advertisements.

Lem includes a remarkable short dialogue in the final of the book. The main character desperately tries to understand the roots of evil and exclaims: 'But there should be anyone knowing the truth!' [Lem, Kandel, 2017, p. 180]. 'Should be', generally speaking, from the point of view of society as a whole. But it is not in the interests of politicians, corporations and federal agencies,' - is the reply.

In the film, a president of the omnipresent entertainment corporation (having at its disposal such sovereign institution, as the police, which hints at its prevalent power in the society represented) presents to the cheering crowd 'the chemical formula of the freedom of choice $^{\text {t5 }}$. I believe it to be a perfect example of how late-capitalist (postmodern) society manipulates imagination, depriving of inalien-

\footnotetext{
The Congress, 2013, dir. Ari Folman.

The Congress 0:52:40 ff.

The Congress 01:07:50 ff.
} 
able and imprescriptible right to choose creating the ubiquitous opium: 'it will be launched and will be available to everyone without exception'.

Interesting enough, that the animated character whose appearance is similar to the one of Bill Gates presents this unique substance. Is it the hint at Microsoft, probably the most influential global corporation? Later he details the nature of the 'chemical revolution'. This turning point is the end of 'the structure'. Everyone would able to drink a substance and be whomever they want to be (in the virtual, hallucinogenic dimension). An ideal world 'without envy, frustration, egoism', where he or she can become his or her dream, is to come. From this point of no return, they proclaim, the animation zone will not be a mere attraction, it will become everyone's life. Guy Debord notes that the spectacle takes roots in the economy of the excess [Debord, 1995, p. 58]. In the case, seemingly, this excess is the wish and the ability to entertain.

To mock this shocking affront to the nature and human dignity, Lem uses a large number of sarcastic descriptions - e.g., sets the action in apartments on the hundredth floor with a palm garden with a female orchestra performing Bach concerts with a support of a collective striptease[Lem, Kandel, 2017, p. 3]. Overconsumption becomes exposed to countless impressions invoking the Biblical notions of Babylon or Sodom and Gomorrah.

The film shows how the entertainment business effectively distracts the attention from the real problems, introducing to the discourse some false ones ${ }^{6}$. The character sees how her cameo makes canned speeches to convince everyone that the people must measure their record against the robots. The latter become 'exhausted', and 'discarded', and society has to make continuous efforts to fight for justice. What happens to people, seemingly, does not serve the broader collective interest. The movie makes it evident that in society, the Spectacle is the priority issue for all. Robyn Wright (Robyn Wright) appeals to the people from the stage to channel the resources to severe problems, such as research on incurable deceases, but not only she is not heard but is stigmatized.

That is what Guy Debord pointed out. The poverty unites everyone involved in the spectacle and its controversies. That is but the way to hide from the horror and the grief of reality [Debord, 1995, \#63]. In 2018, the New York Times published an article arguing that besides the digital divide ${ }^{7}-$ an unequal access to the opportunities and resources by different social groups depending on the equipment - we are witnessing the reverse tendency. The rich tend to prefer offline services and activities, them becoming a luxury e.g., private schools using only analogue sources. On the contrary, the children of the poor spend all their time with gadgets, them damaging the mental health and venturing the opportunities for the harmonious development.

We can observe other examples of the virtual manipulations in our everyday lives. On the Web people, inspired by the corrupting permissiveness and impunity, express their secret wishes and reveal the hidden personal traits. Psychoanalytical Lacanian theory suggests that this is natural for neurotic's behaviour. A neurotic tends to repress the trauma produced by the encounter with the Real ${ }^{8}$. Still, the more it is being suppressed, the more it returns to disrupt the carefully constructed symbolic reality. Slavoj Žižek argues that the cyberspace is 'a key symptom of our ideological constellation' [Zizek, 1997, p. 130], meaning that it is in the virtual reality that the repressed impulses and nurtured hopes fully realize themselves. Moreover 'the diagnosis of the individual is always already a socio-symbolic (collective) diagnostic' [6].... Therefore, analyzing the way the 'spectacle' is performed, we come to a better understanding of what is behind it. People trapped in virtual reality are often the victims of their helplessness. Simi-

\footnotetext{
6 The Congress 0:54:00 ff.

Bowles, Nellie, The Digital Gap Between Rich and Poor Kids Is Not What We Expected. The New York Times (October 26, 2018).

8 Lacanian Real, more specifically, 'that which resists symbolization absolutely'.
} 
larly, society transgressing the boundaries of the reality is helpless and doomed.

Over time, in The Congress, the imaginary system progresses irreversibly. Only a few can see the actual state of things, and only for a short time. In reality, humanity does not escape with dignity the complete collapse of civilization: ill people hoping to survive, dreary and purposeless existence, ecological catastrophe. Lem is more precise in the description of the fall of human civilization. He indicates that the realm of the real is evaporating at an unprecedented speed [Lem, Kandel, 2017, p. 174]. Overproduction, injustice in the distribution of resources, corruption were the reasons for the irreversible degradation. Disguise is the only considerable success. The world is a corpse that has been perfectly preserved for a long time.

As Žižek puts it, capitalism is based on the unconditional trust of the individuals in the fairness inherent in the existing system [Zizek, 2008, p. 2]. Developing the idea, we come to a natural conclusion that, like in any ideology, it hides the elements that do not fit in. Those could be the excluded members of society (e.g., the unemployed, or any other group without access to the benefits). Alternatively, we could switch our attention to moral, cultural elements: dignity, self-efficacy and self-discipline, control over one's actions and desires. These core values in the individual, which in Western civilization for centuries have been regarded as the most important ones for a society's survival and development ${ }^{9}$, are precisely what is being discarded nowadays by the capitalist 'consumerist ethic'. What awaits us?

Structural analysis reveals that it is nothing else than 'The necessity, the absolute certainty, that within the field of a universal lie the repressed truth will emerge in a guise of a particular contingent event' [Zizek, 1997, p. 130]. In the book, it is the progressing inability of the ruling class both to sustain the image and to conceal the truth.
How does it happen that the Spectacle is destined to be 'grasped in its totality'? Žižek asserts that every society at some paradoxical point orders an individual to embrace freely and voluntarily its core impositions [Zizek, 1997, p. 27]. It is, of course, the deadlock: having refused, to a certain extent, one becomes an outcast.

In the book, the system is called 'the secret chemiocracy. No one truly knows what is going on, and if they do, people are made to forget with the use of psychotropic substances. The rulers, by their words, are forced by circumstances. Being in command of the high moral ground is no advantage. If one cannot change reality, one needs to conceal it somehow at least [Lem, Kandel, 2017, p. 180]. Does this last humane, human duty prevent the world from collapsing into the abyss of universal agony not resemble the rhetoric of the burden of the white man?

The movie corresponds more to the point of Žižek. There, the way out is blocked by fear. One of the main animated characters explains that only the brave minority decides to stay in the harm's way and see the dreary truth. Some others carry with them pills, blocking the effect from hallucinogens, but they are too scared to use it. No one has returned from there yet, and if so, it should resemble rising from the dead ${ }^{10}$.

In the postmodern (late-capitalist) world, the mode of production has a harmful impact on society: people become disoriented by the advertisements and brands' PR campaigns, confusing them with universal values. The sphere of entertainment, probably, reflects this best of all. People nowadays become immersed in 'fantasies' and vicious consumerist circle, imposed on them deliberately. Contemporary commodity fetishism is also very special, as it relates not only to goods but also to appearances and ideas linked to them. This co-dependency works both ways. It is the idea of the product that is most important. The real quality of a product (be it food or movies) gets

9 Max Weber in The Protestant Ethic and the Spirit of Capitalism attributes the prosperity of 'developed' Western societies to these Christian personal qualities.

10 The Congress 01:34:00 ff. 
worse and worse. It was Stanislaw Lem who prophetically showed this process in 1971. Taking it to the extreme, in his book 'The Futurological Congress' he demonstrated, how our behaviour makes us 'victims of fetishist illusion' and in the long-term perspective results in the death of civilization. It is no coincidence that his work, being a parody of capitalist society, is up to date and keeps inspiring new creative works. The principal conclusions we can derive from it are the necessity to stop burying heads in the sand. The global problems - of the ecology, poverty, health, conflicts - arise from the global capitalism omnipresence. People should break free from the net of images and start thinking for themselves, focusing on real cause-and-effect relationships.

\section{Список литературы:}

Benjamin W. The work of art in the age of mechanical reproduction / W. Benjamin, J.A. Underwood. London : Penguin Books Ltd, 2008. - 110 p.

Debord G. The society of the spectacle. - New York : Zone Books, 1995. - 154 p.

Klein N. No logo : no space, no choice, no jobs. — London : Fourth Estate, 2010. — 502 p.

Lem S. The futurological congress / S. Lem, M. Kandel. — London : UK Penguin Classics, 2017. — 128 p.

Zizek S. The plague of fantasies. — London; New York : Verso, 1997. — 248 p.

Zizek S. In defense of lost causes. — London; New York: Verso, 2008. — 530 p.

Zizek S. First as tragedy, then as farce. — London; New York: Verso, 2009. — 157 p.

\section{References:}

Debord G. The society of the spectacle. New York: Zone Books, 1995. 154 p.

Zizek S. The plague of fantasies. London; New York: Verso, 1997. 248 p.

Klein N. No logo : no space, no choice, no jobs. London: Fourth Estate, 2010. 502 p.

Benjamin W., Underwood J.A. The work of art in the age of mechanical reproduction. London: Penguin Books Ltd, 2008. 110 p.

Lem S., Kandel M. The futurological congress. London: UK Penguin Classics, 2017. P. 128.

Zizek S. First as tragedy, then as farce. London; New York: Verso, 2009. 157 p.

Zizek S. In defense of lost causes. London; New York: Verso, 2008. 530 p.

\section{Information about the author}

Daria S. Litova - MGIMO University alumna (International Relations - Area Studies), MA student in Cultural Narratives and Comparative Literature (triple degree of the University of St Andrews, Universidade NOVA Lisboa\&Université de Perpignan) (Portugal)

Conflicts of interest. The author declares absence of conflicts of interest. 


\section{Информация об авторе}

Дарья Сергеевна Литова — магистрант образовательной программы Erasmus Mundus по специальности «Пересечения культурных нарративов», финансируемой Европейской Комиссией. Программа тройного диплома университетов Сент-Эндрюс (Шотландия), НОВА (Португалия), Перпиньяна (Франция); Университет НОВА в Лиссабоне, Факультет социально-гуманитарных наук (Португалия)

Конфликт интересов. Автор заявляет об отсутствии конфликта интересов.

The article was submitted 8.10.2020; approved after reviewing 01.12.2020; accepted for publication 30.12.2020.

Статья поступила в редакцию 8.10.2020; одобрена после рецензирования 01.12.2020; принята к публикации 30.12.2020. 